\title{
Customer Relationship Management and Brand Image's Influence on Loyalty through Decision to Stay
}

Submitted Date : 29 April 2021

Accepted Date :

7 September 2021
Meylani Tuti

STIE Pariwisata Internasional, Jakarta, Indonesia meylanituti@stein.ac.id

Nanda Putri Wicaksono STIE Pariwisata Internasional, Jakarta, Indonesia nandaputri272@gmail.com

\section{Suggested Citation:}

Baashar, Y., Alhussian, H., Patel, A., Alkawsi, G., Alzahrani, A. I., Alfarraj, O., \& Hayder, G. (2020). Customer relationship management systems (CRMS) in the healthcare environment: A systematic literature review. Computer Standards and Interfaces, 71(March), 103442. https://doi.org/10.1016/j.csi.2020.103442

Abstract:

The study's aim is analyzing the influence of management of customer relationship and brand image on loyalty by way of decision to stay. Population of this study was guests who stayed more than twice at Santika Taman Mini Hotel. The sampling technique uses purposive sampling to obtain 243 respondents. The method of data analysis is quantitative descriptive. The quantitative analysis is done by the use of SEM (Structural Equation Modeling). The results of this research indicate that customer relationship management has a significant which gives influence on stay decision, brand image has got influence which is significant on decision to stay, customer relationship management has a significant influence on loyalty, brand image has a significant influence on loyalty, decision to stayhas a significant on loyalty, customer relationship management has an influence that is indirect on loyalty through decision to stay, and brand image has an indirect influence on loyalty through decision to stay.

Keywords: Brand Image; Customer Relationship Management; Loyalty; Staying Decision

JEL Classification: M31

*Corresponding Author 


\section{Research Background}

Changes in the uncertain business environment, especially in the hotel industry, have made business people more creative and innovative in managing their companies to survive in the competitive world of business. The development of technology, information, communication, and knowledge made companies realize that the company's orientation is no longer on how to increase sales volume but is more oriented towards acquiring loyal customers. It is necessary to have a unique marketing strategy to create loyal customers to maintain customers who are loyal, and customers would not turn to other companies.

Customer relationship management or commonly referred to as CRM, is the process of managing information in details about each customer and mindfully managing all customer "touchpoints" to optimize the loyalty of customer (Kotler \& Keller, 2006). Awareness of building relationship of customer management is critical in a company, especially those engaged in hospitality. When the customer relationship management of a hotel is going well, this will be an impetus for customers to make the Hotel their first choice when they stay.

Purchasing decisions are the process of a decision of customer to buy a service or product service by going through a decision process before and at the time of making a purchase (Kotler \& Armstrong, 2008). Consumer decision-making includes all the processes that the consumers carry out to recognize problems, search for solutions, examine alternatives, and pick out between options. Previous research has shown a relationship between CRM and staying decisions (Kusumandayu, 2016).

Brand image is a series of ideas, beliefs, and customer impressions toward a brand; hence, customer attitudes and actions towards a brand tend to be dependent on the image of brand (Song, Wang, \& Han, 2019). Previous research has shown a relationship between brand image and decision to stay (Pramudyo, 2012). Consumers tend to choose products known both through experience and based on information obtained through various sources. Brand image is one factor to generate customer loyalty to a particular brand of the product being offered.

Loyalty, in general, can be defined as one's loyalty to a product, both certain goods, and services. Also, customers who are highly committed to their loyalty will not be influenced by forms of product marketing for services provided by other companies and will choose the products and services they previously chose. Loyalty of customer is a solid commitment to repurchase or re-pattern consistently the service or product used in the future even though situational marketing and influences stimuli can cause behavior change (Oliver, 1999). Loyal customers will be happy to express positive things and provide recommendations about the company to others. Loyalty is a result achieved by the company to continue to stand in the fierce competition. It is better to retain old customers who make repeat purchases and recommend them to others than to find new customers. Previous research has shown a relationship between staying decisions and customer loyalty (Diansyah \& Putera, 2017).

Previous research has shown that brand image is the originator of trust and satisfaction. Satisfaction has a positive relationship with brand loyalty (Han et al., 2018). Brand image has an effect on purchasing decisions (Annisa Ristanti, 2020; Gifani \& Syahputra, 2017), while in other studies it is stated that brand image has no effect on purchasing decisions (Deisy, Lapian, \& Mandagie, 2018). In another different study, it was determined that brand image partially had no significant effect on consumer loyalty (Rosanti, 2021). There is a relationship between customer relationship management and the decision to stay (Kusumandayu, 2016) and Zuhri \& Palupiningsih stated that customer relationship management and brand image have a significant effect on customer loyalty through satisfaction (Zuhri \& Palupiningdyah, 2018). From the results of the above research, the purpose of this study is to analyze the relationship between CRM and brand image on loyalty through the decision to stay without going through satisfaction as has been done in previous studies.

Customer relationship management or commonly referred to as CRM, is the process of management of detailed information about each customer and managing all customer "touchpoints" carefully to maximize loyalty of customer (Kotler \& Keller, 2006). It is integrating processes and functions that are internal and networks that are external (Buttle, 2009). Combine technology and relationship marketing strategies to generate long-term relationship benefits (Payne, Storbacka, \& Frow, 2008). They manage all relationships with interactive processes, various contacts,, and elements of communication (Nyadzayo \& Khajehzadeh, 2016). Improve customer retention, customer acquisition, customer profitability, and customer loyalty (Kotler \& Armstrong, 2008). Innovations must be managed properly to maximize operational efficiency and competitiveness for a sustainable company (Cruz-Jesus, Pinheiro, \& Oliveira, 2019). The relationship is mutually beneficial from the seller's perspective (Richards \& Jones, 2008). Management of customer relationship is also defined as a comprehensive process and strategy for partnering, acquiring, and retaining with selective customers to create value which is superior for the customers and company. It covers sales, customer service, integrating marketing, and an organization's supply chain functions to obtain better efficiency and influenceiveness in delivering value of 
customer (Parvatiyar \& Sheth, 2001). A viewpoint covering all business cycles (Ghalenooie \& Sarvestani, 2016) and data-connected technology allows higher profits or an approach that is strategic that gives value (Triznova, Mat'ova, Dvoracek, \& Sadek, 2015). Then, Yahia argued that customer relationship management includes innovative technology that looks for increasing satisfaction of customer, loyalty, and profitability by influenceively developing, acquiring, and maintaining customer interactions and relationships (Baashar et al., 2020).

The program of CRM will be described as follows (Parvatiyar \& Sheth, 2001): 1. Continuity Marketing, maintaining, and increasing customer loyalty through special services that are long-term. 2. One to One Marketing is a program carried out individually to fulfill customers' unique needs. 3.Partnering Program, a partnership relationship between customers and marketers to serve the needs of end consumers.

Image of a brand is a theory that advises consumers to purchase a particular brand by putting into consideration the physical functions and features of that brand (Song et al., 2019). Brand image is also defined as a reflection of a brand in consumers' memory (Lahap, Ramli, Said, Radzi, \& Zain, 2016). The statement reinforces that brand image is what has come to consumers' minds when a brand is put in display in front of consumers. When customers judge a brand name, they will think spontaneously about the features of that brand. This creation is created on the basis of personal experience or hearing about its reputation from the media or other people (Nyadzayo \& Khajehzadeh, 2016).

In the tourism industry, image of brand is one of the main factors for guests to consider in terms of recommendations and even intention to buy (Mohammed \& Rashid, 2018). Image of brand is considered as perception about a brand as portrayed by the association of brand held by consumers (Sürücü et al., 2019). A strong brand has a clear identity. Consumers generally want something unique and distinctive associated with the brand. To measure brand image, it can be implemented based on the brand aspects (Keller, 2003), namely Strength, Uniqueness, and Favorable.

The purchase decision is buying the best preferred brand, but these two factors can be between the buyer's intention and the buying decision (Kotler \& Armstrong, 2008). If the consumer has made decision which alternative to pick out and maybe a substitute if needed, he will purchase. Purchases involve consumer decisions about what to purchase (Sumarwan, 2014). Consumer's process of making decision is a process of solving problems that are aimed at the target. In other words, an integration process that unites knowledge to evaluate two or more alternative behaviors and picks out one of them (Sangadji \& Sopiah., 2013).

The purchasing decision is a dynamic process that includes different stages. The purchase decision process involves five stages (Karimi, Papamichail, \& Holland, 2015), namely Problem Introduction, Search for Information, Alternatives Evaluation, Purchase decision, and Post-purchase behavior.

Loyalty of customer is a commitment to repurchase or subscribe to a preferred product or service consistently in the future, regardless of influences which are situational that can cause behavior change (Marakanon \& Panjakajornsak, 2017). Recommend to others repeatedly (Lawfer, 2004). Another opinion said as a key in service marketing (Sürücü et al., 2019) as a commitment from a customer to a service or product as measured by repurchase or attitudinal commitment (Muhammad, 2015).

Loyalty is sometimes referred to as a character trait, such as when we say that someone is loyal (Kotler \& Keller, 2006), a loyal person will show purchasing behavior from time to time (Budi, 2013), loyalty of customer is described as the relationship strength between relative attitudes as well as repeated purchases (Zuhri \& Palupiningdyah, 2018) as evidence of the preferences of main customers, further argued that loyalty is customer loyalty which is done voluntarily with the assumption that it is in the market mechanism. Loyal customers are defined as customers who make repeated purchases (repeat customers).

Customer loyalty is formed through a long process. Customers have gone through a learning process (experience) from continuous purchases made themselves; when consumers feel that they have gotten what they expect, they will make repeated purchases. (Zuhri \& Palupiningdyah, 2018). The concept of brand loyalty is consistent purchasing behavior towards the brand (Ansari \& Riasi, 2016). Loyalty of customer is an essential aspect of management of marketing and includes repeat purchases, brand pressure, customer satisfaction, and others (Borishade et al., 2018). Loyalty indicators (Cahill, 2007) are Repurchases, Additional Purchase, and Referrals. 


\section{Research Method}

The variables observed consisted of 4 variables, namely CRM, image of brand, the decision to stay, and loyalty. Twenty-one items involve the process of measuring of exogenous variables such as six items of CRM, five items of brand image, five items of the decision of stay, and endogenous variables such as five loyalty items. The scaling measurement implemented in this study is the 5-point Likert scale. The demographics variables questioned are gender, age, occupation, and frequency of stay. The sample utilized in this research were repeater guests of Santika Taman Mini Hotel Jakarta. The sampling technique being carried out was purposive sampling, namely guests who have stayed at the Santika hotel twice or morewith as many as 253 guests. After going through the outlier's process, the remaining data was 243 respondents. In this study, an inferential statistic will be utilized to examine the influence of CRM and brand image on decision to stayand loyalty. The SEM LISREL was used for the inferential statistic. The analysis of second-generation is of multivariate technique is conducted to measure the connection among latent mediator, mediator effects, independent, dependent variables, and testing models (Latan \& Ramli, 2013).

\section{Results}

CFA was carried out to test the model of measurement, appropriateness of data, validity which is convergent and discriminant. Table 1 gives the standardized factor loadings and constructs reliability from validity which is convergent (Hair, JF., Black, WC., Babin, BJ., Anderson, RE., Tatham, 2010). A total of 21 items are utilized in the model of measurement. There were no validity and reliability issues in the data because all the loadings and constructs met the recommended reliability and validity criteria (Henseler, Ringle, \& Sarstedt, 2015). First, every measurement had a significant factor loading that ranged from 0.660 to 0.920 . The critical ratio (t-value) is higher than the critical level of 1.96 and p-value of $0.05(5 \%)$. Secondly, for reliability of construct, the composite reliability and Cronbach's Alpha of all the constructs were more significant than the recommended 0.70 cut-offs (Nunnaly \& Bernstein, 1994). The range of values is between 0.740 and 0.890 , that suggests that every factor was well measured by all measurements in significant way. Third, the AVE or average variance extracted values range from 0.510 to 0.780 , which is higher than 0.5 , which gives evidence of validity which is convergent (Hair, JF., Black, WC., Babin, BJ., Anderson, RE., Tatham, 2010). The discriminant validity analysis results presented in Table 1 indicate that all of the constructs are distinct from each other. Moreover, all the other correlations had less than the AVE square root for each construct (Henseler et al., 2015).

Table 1. Construct Reliability, Average Variance Extracted and Discriminant Validity

\begin{tabular}{cccccc}
$\begin{array}{c}\text { Variable } \\
\text { and Scale } \\
\text { Items }\end{array}$ & $\begin{array}{c}\text { Standarized } \\
\text { Loading }\end{array}$ & $\begin{array}{c}\text { Error } \\
\text { Variance }\end{array}$ & $\begin{array}{c}\text { Constuct } \\
\text { Reliability }\end{array}$ & $\begin{array}{c}\text { Average Variance } \\
\text { Extracted }\end{array}$ & $\begin{array}{c}\text { Discriminant } \\
\text { Validity }\end{array}$ \\
\hline X1.1 & 0,66 & 0,57 & & & \\
X1.2 & 0,60 & 0,64 & & & \\
X1.3 & 0,66 & 0,56 & 0,74 & 0,51 & 0,71 \\
X1.4 & 0,74 & 0,45 & & & \\
X1.5 & 0,75 & 0,44 & & & \\
X1.6 & 0,83 & 0,31 & & & \\
X2.1 & 0,89 & 0,21 & & & \\
X2.2 & 0,86 & 0,26 & & & \\
X2.3 & 0,90 & 0,20 & 0,87 & & \\
X2.4 & 0,92 & 0,15 & & & \\
X2.5 & 0,75 & 0,44 & & & \\
Y1.1 & 0,65 & 0,58 & & & \\
Y1.2 & 0,71 & 0,49 & & & \\
Y1.3 & 0,83 & 0,31 & 0,82 & 0,64 & \\
Y1.4 & 0,82 & 0,33 & & & \\
Y1.5 & 0,96 & 0,08 & & & \\
Y2.1 & 0,84 & 0,30 & & & \\
Y2.2 & 0,89 & 0,20 & & & \\
Y2.3 & 0,85 & 0,28 & 0,89 & 0,78 & \\
Y2.4 & 0,92 & 0,16 & & & \\
Y2.5 & 0,92 & 0,15 & & & \\
\hline
\end{tabular}

Source : Data Processed (2021) 
Table 2 The Confirmatory Factor Analysis Results

\begin{tabular}{llll}
\hline Goodness Of Fit & Fit Measurement & Result & Notes \\
\hline $\begin{array}{l}\text { Root Mean Square Error of Approximation } \\
\text { (RMSEA) }\end{array}$ & $\begin{array}{l}\leq, 08 \text { is (good fit), if RMSEA }<0.05 \text { is } \\
\text { close fit }\end{array}$ & 0,110 & marginal fit \\
$\begin{array}{l}\text { Model CAIC (Consistent } \\
\text { Information Criterion) }\end{array}$ & Akaike & & \\
Independence CAIC & CAIC less than CAIC model saturated & 1045,330 & \\
Saturated CAIC & and independence means model fit & 16869,230 & good fit \\
Normed Fit Index (NFI) & & 1499,900 & good fit \\
Non-Normed Fit Index (NNFI) & $\geq 0.90$ & 0,95 & good fit \\
Comparative Fit Index (CFI) & $\geq 0.90$ & 0,96 & good fit \\
Incremental Fit Index (IFI) & $\geq 0.90$ & 0,96 & good fit \\
Relative Fit Index (RFI) & $\geq 0.90$ & 0,96 & good fit \\
Root Mean Square Residual (RMR) & $\geq 0.90$ & 0,95 & good fit \\
Standarized RMR & $\leq 0.10$ & 0,052 & good fit \\
Goodness of Fit Index (GFI) & $\leq 0.10$ & 0,082 & marginal fit \\
Adjusted Goodness of Fit Index (AGFI) & $\geq 0.90$ & 0,72 & marginal fit \\
\hline
\end{tabular}

Source : Data Processed (2021)

This study conducted a confirmatory factor analysis to evaluate the measurement model's overall validity and fit of the constructs. The key goodness-of-fit indices for the measurement model are tested $(\mathrm{Hu}, \mathrm{Bentler}, \mathrm{\&}$ $\mathrm{Hu}, 2009)$. Based on the measurement model fit, the overall Normed Fit Index $(\mathrm{NFI})=0.95$, Comparative Fit Index $(\mathrm{CFI})=0.96$, Incremental Fit Index $(\mathrm{IFI})=0.96$, and Root Mean Square Residual $(\mathrm{RMR})=0.0052$, indicate good fit (Hair, JF., Black, WC., Babin, BJ., Anderson, RE., Tatham, 2010). Although the GFI does not meet their suggested cut-off value of 0.90 , and RMSEA is marginal fit, respectively, all other fit indices meet the recommended value. Hence, the model gives strong evidence of a good fit of the model (Steiger, 1980), as shown in Table 2.

Based on the table 3, all statistically observed variables with a significance level of $5 \%$ have been considered valid. This is because all the variables observed in the standardized loading factor measurement model have a value of $\geq 0.50$. Statistically, the standardized loading factor above has been considered valid and significant. The feasibility test of the model shows that this model is by the data or fit the data used in the study; the suitability can be witnessed in table 3 . The test of the feasibility of the model shows that this model is by the data or fit the data used in the study, as seen in the following table:

Tabel 3. Summary of Hypothesis Tests

\begin{tabular}{lcccccc}
\multicolumn{1}{c}{ Path } & Estimation & t-value & $\begin{array}{c}\text { Critical } \\
\text { value }\end{array}$ & Result & Notes \\
\hline CRM (X1) $\rightarrow$ Stay Decision (Y1) & 0,16 & 2,03 & 1,96 & Significance & Accepted \\
Brand Image (X2) $\rightarrow$ Stay Decision (Y1) & 0,70 & 9,54 & 1,96 & Significance & Accepted \\
CRM (X1) $\rightarrow$ Loyalty (Y2) & 0,11 & 2,31 & 1,96 & Significance & Accepted \\
Brand Image (X2) $\rightarrow$ Loyalty (Y2) & 0,16 & 2,47 & 1,96 & Significance & Accepted \\
Stay Decision (Y1) $\rightarrow$ Loyalty (Y2) & 0,73 & 8,17 & 1,96 & Significance & Accepted \\
CRM (X1) $\rightarrow$ Stay Decision (Y1) $\rightarrow$ Loyalty (Y2) & 0,12 & 2,16 & 1,96 & Significance & Accepted \\
Brand Loyalty (X2) $\rightarrow$ Stay Decision (Y1) $\rightarrow$ Loyalty (Y2) & 0,51 & 7,15 & 1,96 & Significance & Accepted \\
\hline
\end{tabular}

Source : Data Processed (2021)

Table 3 shows that the results of path analysis is based on multiple coefficients of determination $\left(R^{2}\right)$, path coefficients $(\beta)$, and t-values. The results indicate that all hypotheses are well supported. As predicted, positive path coefficients are having significant role between two variable exogenous (CRM and brand image) and two variable endogenous (decision to stayand loyalty), including $\mathrm{H} 1$ : $\mathrm{CRM} \rightarrow$ Decision to $\operatorname{stay}(\beta=0.16, t=2.03), \mathrm{H2}$ : brand image $\rightarrow$ decision to stay $(\beta=0.70, t=9.54), \mathrm{H} 3: \mathrm{CRM} \rightarrow$ loyalty $(\beta=0.11, \mathrm{t}=2.31), \mathrm{H} 4$ : brand image $\rightarrow$ loyalty $(\beta=0.16, t=2,47, \mathrm{H} 5$ : decision to stay $\rightarrow$ loyalty $(\beta=0.73, \mathrm{t}=8.17, \mathrm{H} 6: \mathrm{CRM} \rightarrow$ decision to stay $\rightarrow$ loyalty 
$(\beta=0.12, t=2.16)$ and $H 7:$ brand image $\rightarrow$ decision to stay $\rightarrow$ loyalty $(\beta=0.51, t=7.15)$. However, the results demonstrate CRM and image of brand have a significant influence on both decision of staying and loyalty.

\section{Discussion}

\section{Customer Relationship Management and Brand Image on Decision to Stay}

The result showed that decision to stay is influenced by CRM with a t-value of $2.03 \geq 1,96$ and brand image with a t-value 9,54. CRM is a 360-degree view of customer-based management and is advancement and improvement in communication with customers, which states that the point of view must include all business cycles. All of the departments of an organization, such as accounting, marketing, production, and others, give attention to customers and their needs and share information. All communication points with customers must be controlled, and the most detailed information of customers must be converted into valuable data between people and departments (Ghalenooie \& Sarvestani, 2016). The tourism industry must focus on services. Satisfied customers will not hesitate to use the product regularly. CRM is a business strategy to maintain customers by improving relationships and building better communication to have a positive impression. A previous study showed the relation between CRM and decision to stay (Kusumandayu, 2016; Sholeh, 2019).

A previous study supported the influences of brand image on decision to stay, which showed the relation between brand image and decision to stay(Gifani \& Syahputra, 2017; Ristanti, 2020). In the tourism industry, brand image is one of the main factors for guests to consider recommendations and even intention to buy (Mohammed \& Rashid, 2018). Brand image can stick in the minds of consumers, even if they are not dealing directly with a product. Building a positive brand image and having the advantages highlighted will leave a positive impression on consumers because it is the main factor in differentiating a brand from other brands. When consumers make brand choices, consumers must decide which brand to buy. In this case, the company must know how consumers choose a brand.

\section{Customer Relationship Management and Brand Image on Loyalty}

The result showed that loyalty is influenced by CRM with a t-value of $2.31 \geq 1,96$ and brand image with a t-value $2.47 \geq 1,96$. CRM is an technology which is innovative that tries to increase satisfaction of customer, loyalty, and profitability by acquiring, maintaining and developing customer interactions and relationships influenceively (Baashar et al., 2020). Customer loyalty is defined as a firmly held commitment to repurchase or subscribe to a preferred product or service consistently in the future, regardless of situational influences and marketing efforts that have the potential to cause behavior change (Marakanon \& Panjakajornsak, 2017). Loyal customers will continue to purchase if they feel satisfied. The survival of a business is determined by the methods used to satisfy consumer needs according to what is expected and exceeds it. Maintaining existing customers is more difficult than finding new customers. The company must provide a strategy that aims to retain customers by building good relationships. A previous study found the relationship between CRM and loyalty (Zuhri \& Palupiningdyah, 2018).

The brand image reflects a brand in the memory of consumers (Lahap et al., 2016). Image of brand is substantially what comes to the mind of consumer when a brand is placed in front of the customer. In other words, when customers judge a brand name, they spontaneously think about the brand features. Loyalty arises because of a sense of trust from consumers after using a product. Brand image is essential in increasing consumer's belief in the brand and how consumers perceived the brand. If the perception is good, consumers will buy, even willing to pay high and make repeat purchases; if the image is not good, consumers will move to another brand. It can be said that loyalty occurs because there is an influence on the image of brand. This hypothesis supported by previous study which showed that brand image has got a relation which is positive with loyalty (Agmeka, Wathoni, \& Santoso, 2019; Pramudyo, 2012).

\section{Decision to Stay on Loyalty}

The result showed that loyalty is influenced by decision to stay with a t-value of $8.17 \geq 1,96$. Brand image to loyalty through decision to stay with a t-value $7.15 \geq 1,96$, and CRM to loyalty through decision to stay with a tvalue $2.16 \geq 1,96$. The purchase decision is a process of consumer decisions to buy products/services (Kotler \& Armstrong, 2008). At the same time, loyalty of customer is an essential aspect of marketing management and includes brand pressure, repeat purchases, customer satisfaction, etc. (Borishade et al., 2018). The desire to repeat purchases happen when the customer feels that their needs are met and even exceed expectations, and it led to continuous purchases even a loyal attitude. A previous study showed a positive relation between purchase decisions and loyalty (Hatta \& Setiarini, 2018). 
A previous study showed an indirect influence of CRM on loyalty through purchase decisions (Diansyah \& Putera, 2017; Kusumandayu, 2016). CRM is considered a technology related to data, which allows higher profits or a strategic approach that gives value (Triznova et al., 2015). Meanwhile, customer loyalty is formed through a long process, where customers have gone through a learning process (experience) from continuous purchases made by themselves (Zuhri \& Palupiningdyah, 2018). CRM act as a marketing strategy to gain customer trust and getting close with customers. The closeness and trust of customers in a service or product will create the desire of customers to reuse and even increase customer loyalty to a product or service provider. Also, when communication between companies and customers goes well, it will make it easier to market the products or services, and $t$ will form purchase decision intentions even to repeat purchases and produce loyal customers. This result supported by previous study which point out indirect influence between brand image and loyalty through staying decision.

Brand image is considered one of the most important assets which are not tangible that impact consumer perceptions in companies (Agmeka et al., 2019). Loyalty is a concept that is two-dimensional and views loyalty of brand as a consistent purchasing behavior which is a consequence of a positive attitude towards the brand (Ansari \& Riasi, 2016). Meanwhile, the purchase decision is a process of problem-solving directed at the target, in other words, an integration process that combines knowledge to evaluate two or more alternative behaviors and select one of them (Sangadji \& Sopiah., 2013). The Previous study showed that brand image positively impacts loyalty through decision to stay(Song et al., 2019; Zuhri \& Palupiningdyah, 2018). A good brand image will create a positive perception in the eyes of consumers. Customers tend to remember the brand when they want to use its services or products compared to other brands. Image of brand is an important aspect connected to the product. If the product produced is good and of good quality, then the product has more value in the minds of consumers so that it will enhance the brand image. When buying a product, consumers do not only buy a product but see the symbolic value of the brand. So that it raises the consumer's desire to make a purchase decision, when consumers feel confident in the brand and make repeat purchases continuously, there is loyalty.

\section{Conclusion}

This work analyzes the CRM's influence, the brand image on loyalty through staying decision. The finding showed that all exogenous variables have got a significant favorable influence on all endogenous variables. The results or findings are put into consideration to offer a new model by finding the influences of decision to stay directly to loyalty without passing through satisfaction or trust. Limitation of this research is that it only uses one branch of the Santika hotel, it does not cover various other branches of the Santika hotel, so it is recommended for further research to expand the object of research so that it gets more descriptive results by using variables other than CRM and brand image.

\section{References}

Agmeka, F., Wathoni, R. N., \& Santoso, A. S. (2019). The influence of discount framing towards brand reputation and brand image on purchase intention and actual behaviour in e-commerce. Procedia Computer Science, 161, 851-858. https://doi.org/10.1016/j.procs.2019.11.192

Ansari, A., \& Riasi, A. (2016). Modelling and evaluating customer loyalty using neural networks: Evidence from startup insurance companies. Future Business Journal, 2(1), 15-30. https://doi.org/10.1016/j.fbj.2016.04.001

Baashar, Y., Alhussian, H., Patel, A., Alkawsi, G., Alzahrani, A. I., Alfarraj, O., \& Hayder, G. (2020). Customer relationship management systems (CRMS) in the healthcare environment: A systematic literature review. Computer Standards and Interfaces, 71(March), 103442. https://doi.org/10.1016/j.csi.2020.103442

Borishade, T. T., Worlu, R. E., Kehinde, O., Ibidunni, A., Ogunnaike, O., Dirisu, J., ... Peter, F. (2018). A dataset of customer loyalty and variation in perception of customers across demographic characteristics In healthcare sector of Nigeria. Data in Brief, 20,353-357. https://doi.org/10.1016/j.dib.2018.08.014

Budi, A. P. (2013). Manajemen Marketing Perhotelan. Yogyakarta: ANDI OFFSET.

Buttle, F. (2009). Customer Relationship Management. (Elsevier, Ed.). USA.

Cahill, D. L. (2007). Customer Loyalty in Third Party Logistics Relationships. Heidelberg, Germany: PhysicaVerlag.

Cruz-Jesus, F., Pinheiro, A., \& Oliveira, T. (2019). Understanding CRM adoption stages: empirical analysis 
building on the TOE framework. Computers in Industry, 109, 1-13. https://doi.org/10.1016/j.compind.2019.03.007

Diansyah, D., \& Putera, R. M. (2017). Pengaruh Ekuitas Merek Dan Promosi Penjualan Terhadap Loyalitas Pelanggan Dimediasi Keputusan Pembelian. Media Ekonomi Dan Manajemen, 32(2), 97-109. https://doi.org/10.24856/mem.v32i2.538

Ghalenooie, M. B., \& Sarvestani, H. K. (2016). Evaluating Human Factors in Customer Relationship Management Case Study: Private Banks of Shiraz City. Procedia Economics and Finance, 36(16), 363-373. https://doi.org/10.1016/s2212-5671(16)30048-x

Gifani, A., \& Syahputra. (2017). Pengaruh Citra Merek Terhadap Keputusan Pembelian Produk Smartphone Oppo Pada Mahasiswa Universitas Telkom. Bisnis Dan Iptek, 10(2), 84. Retrieved from www.gadget.bisnis.com

Hair, JF., Black, WC., Babin, BJ., Anderson, RE., Tatham, R. (2010). Multivariate Data Analysis (5th Editio). Upper Saddle River. New Jersey: Prentice Hall.

Han, H., Nguyen, H. N., Song, H., Chua, B. L., Lee, S., \& Kim, W. (2018). Drivers of brand loyalty in the chain coffee shop industry. International Journal of Hospitality Management, 72(January 2017), 86-97. https://doi.org/10.1016/j.jhm.2017.12.011

Hatta, I. H., \& Setiarini, S. (2018). Pengaruh Word Of Mouth dan Switching Cost Terhadap Keputusan Pembelian dan Loyalitas. Jurnal IImiah Manajemen Dan Bisnis, 19(1), 32-40. https://doi.org/10.30596/jimb.v19i1.1728

Henseler, J., Ringle, C. M., \& Sarstedt, M. (2015). A new criterion for assessing discriminant validity in variancebased structural equation modeling, 115-135. https://doi.org/10.1007/s11747-014-0403-8

Hu, L., Bentler, P. M., \& Hu, L. (2009). Cutoff criteria for fit indexes in covariance structure analysis: Conventional criteria versus new alternatives Cutoff Criteria for Fit Indexes in Covariance Structure Analysis: Conventional Criteria Versus New Alternatives, 5511. https://doi.org/10.1080/10705519909540118

Karimi, S., Papamichail, K. N., \& Holland, C. P. (2015). The effect of prior knowledge and decision-making style on the online purchase decision-making process: A typology of consumer shopping behaviour. Decision Support Systems, 77, 137-147. https://doi.org/10.1016/j.dss.2015.06.004

Kotler, P., \& Armstrong, G. (2008). Prinisp - prinsip manajemen pemasaran, (12th ed.). Jakarta: Erlangga.

Kotler, P., \& Keller, K. L. (2006). Manajemen Pemasaran. New Jersey: Pearson Education.

Kusumandayu, R. (2016). Pengaruh Bauran Promosi, Customer Relationship Management Dan Kualitas Layanan Terhadap Keputusan Tamu Menginap Di Bess Resort \& Waterpark, Hotel And Convention Lawang - Malang. Jurnal Manajemen Science, 7(20), 545-546.

Lahap, J., Ramli, N. S., Said, N. M., Radzi, S. M., \& Zain, R. A. (2016). A Study of Brand Image towards Customer's Satisfaction in the Malaysian Hotel Industry. Procedia - Social and Behavioral Sciences, 224(August 2015), 149-157. https://doi.org/10.1016/j.sbspro.2016.05.430

Latan, H., \& Ramli, N. A. (2013). The Results of Partial Least Squares-Structural Equation Modelling Analyses (PLS-SEM). SSRN Electronic Journal, 1(2013). https://doi.org/10.2139/ssrn.2364191

Lawfer, M. R. (2004). Why Customers Come Back. USA: Career Press.

Marakanon, L., \& Panjakajornsak, V. (2017). Perceived quality, perceived risk and customer trust affecting customer loyalty of environmentally friendly electronics products. Kasetsart Journal of Social Sciences, 38(1), 24-30. https://doi.org/10.1016/j.kjss.2016.08.012

Mohammed, A., \& Rashid, B. (2018). A conceptual model of corporate social responsibility dimensions, brand image, and customer satisfaction in Malaysian hotel industry. Kasetsart Journal of Social Sciences, 39(2), 358-364. https://doi.org/10.1016/j.kjss.2018.04.001

Muhammad, A. (2015). Manajemen Pemasaran Jasa Teori dan Praktek. (Alfabeta, Ed.). Bandung.

Nunnaly, Ju. C., \& Bernstein, I. H. (1994). Psychometric Theory (3rd ed.). San Francisco: McGraw-Hill.

Nyadzayo, M. W., \& Khajehzadeh, S. (2016). The antecedents of customer loyalty: A moderated mediation model of customer relationship management quality and brand image. Journal of Retailing and Consumer Services, 30, 262-270. https://doi.org/10.1016/j.jretconser.2016.02.002

Oliver, R. L. (1999). Whence consumer loyalty? Journal of Marketing, 63(SUPPL.), 33-44. https://doi.org/10.2307/1252099

Parvatiyar, A., \& Sheth, K. (2001). Customer Relationship Management: Emerging Practice, Process, and Discipline. Journal of Economic \& Social Research, 3(2).

Payne, A. F., Storbacka, K., \& Frow, P. (2008). Managing the co-creation of value. Journal of the Academy of Marketing Science, 36(1), 83-96. https://doi.org/10.1007/s11747-007-0070-0 
Pramudyo, A. (2012). Pengaruh Citra Merek Terhadap Loyalitas Melalui Kepuasan Sebagai Intervening ( Studi pada Mahasiswa Perguruan Tinggi Swasta di Yogyakarta ), I(1), 1-16.

Richards, K. A., \& Jones, E. (2008). Customer relationship management: Finding value drivers. Industrial Marketing Management, 37(2), 120-130. https://doi.org/10.1016/j.indmarman.2006.08.005

Ristanti, A. (2020). Pengaruh Kualitas Produk dan Citra Merek Terhadap Keputusan Pembelian Konsumen. IImu Manajemen, 1(2), 472-485.

Sangadji, E. M., \& Sopiah. (2013). Perilaku Konsumen. Yogyakarta: ANDI OFFSET.

Sholeh, A. (2019). Pengaruh Kualitas Layanan Dan Customer Relationship Management Terhadap Keputusan Dan Kepuasan Konsumen Menggunakan Jasa Pt. Federal International Finance Cabang Jember. Journal of Chemical Information and Modeling, 53(9), 1689-1699.

Song, H. J., Wang, J. H., \& Han, H. (2019). Effect of image, satisfaction, trust, love, and respect on loyalty formation for name-brand coffee shops. International Journal of Hospitality Management, 79(June 2018), 50-59. https://doi.org/10.1016/j.ijhm.2018.12.011

Steiger, J. H. (1980). Tests for Comparing Elements of a Correlation Matrix, 87(2), 245-251.

Sumarwan, U. (2014). Perilaku Konsumen. Bogor: Ghalia Indonesia.

Sürücü, Ö., Öztürk, Y., Okumus, F., \& Bilgihan, A. (2019). Brand awareness, image, physical quality and employee behavior as building blocks of customer-based brand equity: Consequences in the hotel context. Journal of Hospitality and Tourism Management, 40(November 2018), 114-124. https://doi.org/10.1016/j.jhtm.2019.07.002

Triznova, M., Mat'ova, H., Dvoracek, J., \& Sadek, S. (2015). Customer Relationship Management Based on Employees and Corporate Culture. Procedia Economics and Finance, 26(15), 953-959. https://doi.org/10.1016/s2212-5671(15)00914-4

Zuhri, M. A. T., \& Palupiningdyah, P. (2018). The Influence of Customer Relationship Management and Brand Image on Customer Loyalty through Satisfaction. Management Analysis Journal, 7(3), 363-373. 